\title{
Comparison of the effect of postoperative care agents on human gingival fibroblasts: a preliminary study
}

\section{Purpose}

The aim of this study is to compare effects of postoperative care agents; chlorhexidine, octenidine dihydrochloride and hyaluronic acid on human gingival fibroblasts' viability, proliferation, apoptosis and migration.

\section{Material and Methods}

After cell culturing; chlorhexidine, octenidine dihydrochloride and hyaluronic acid solutions were applied on cells and nothing was applied for control group. The cells were monitored to investigate cytotoxicity; the percentage of apoptotic, living and dead cells at the time of 24,48 , and 72 hours (h). A scratch wound assay was performed to detect cell migration and cells were monitored at baseline, at 24 and $48 \mathrm{~h}$

\section{Results}

At $24 \mathrm{~h}$, chlorhexidine showed statistically lower percentage of total apoptotic cells' than octenidine dihydrochloride $(p=0.049)$, hyaluronic acid $(p=0.049)$ and control $(p=0.049)$. At $48 \mathrm{~h}$, hyaluronic acid showed statistically lower percentage than chlorhexidine $(p=0.049)$, and control $(p=0.049)$. All agents were found to have statistically and significantly more cytotoxic than control. However, there was no difference between experimental groups for proliferation rate. Octenidine dihydrochloride showed statistically negative effects on cell migration than chlorhexidine and hyaluronic acid at $24 \mathrm{~h}$. Chlorhexidine and hyaluronic acid maintained migration ability of cells than octenidine dihydrochloride at $48 \mathrm{~h}$.

\section{Conclusion}

All agents have similar effects on cell behavior such as viability, apoptosis and cell proliferation. However, octenidine dihydrochloride showed statistically negative effects on migration ability than chlorhexidine and hyaluronic acid.

Keywords: Chlorhexidine; hyaluronic acid; octenidine dihydrochloride; cell viability; cell migration

\section{Introduction}

In oral surgery practice, mouth rinses are used for postoperative care to prevent complications caused by various risk factors including bacterial infection, surgical trauma, insufficient wound care, and poor oral hygiene (1). The healing process begins after oral surgical procedures, and wound care is a key factor for hindering healing complications caused by over inflammatory reactions or infection during the early wound healing process (2). Although bacterial invasion into the wound area is one of the reasons for postoperative infection and mouth rinses are commonly prescribed in order to prevent postoperative complications, oral mouth rinses have some cytotoxic activities that cause fibrinolysis, which can disrupt the wound-healing process (3). There are many postoperative care solutions such as chlorhexidine $(\mathrm{CHX})$, octenidine dihydrochloride $(\mathrm{OCT})$,

\author{
Ugur Mercan ${ }^{1} \mathbb{D}$, \\ Z. Burcin Gonen ${ }^{2} \mathbb{D}$, \\ Hasan Salkin ${ }^{3}$ (D), \\ Gul Merve Yalcin-Ulker ${ }^{1}$ (D), \\ Deniz Gokce Meral'
}

ACBiD $10^{\text {th }}$ International Congress, $13^{\text {th }}$ May 2016, Antalya, Turkey.

ORCID IDs of the authors: U.M. 0000-0003-4935-673X Z.B.G. 0000-0003-2725-9330; H.S. 0000-0001-9404-2348; G.M.Y.U. 0000-0002-7438-5834;D.G.M. 0000-0003-3621-5890

'Department of Oral and Maxillofacial Surgery, Dentistry School, Okan University, Istanbul, Turkey

${ }^{2}$ Department of Oral and Maxillofacial Surgery, Faculty of Dentistry, Erciyes University, Kayseri, Turkey

${ }^{3}$ Department of Histology, Faculty of Medicine, Erciyes University, Kayseri, Turkey

Corresponding Author: Ugur Mercan E-mail:dr.umercan@yahoo.com

Received: 16 January 2018 Revised: 3 May 2018 Accepted: 25 October 2018

DOI: 10.26650/eor.20197456 
povidone iodine, Meridol, and hyaluronic acid (HA). In the recent literature, there are studies about the cytotoxic and antimicrobial effects of these products, and each has its own advantages and disadvantages.

$\mathrm{CHX}$ is the most commonly prescribed antimicrobial mouth rinse after oral surgical procedures. $\mathrm{CHX}$ molecules are symmetrical cationic molecules composed of two 4chlorophenyl rings and two biguanide groups (bisbiguanide) connected by a central hexamethylene chain $(4,5)$. CHX is a substantive antimicrobial mouth rinse and maintains its activity for long periods. Nevertheless, $\mathrm{CHX}$ has been reported as having adverse effects such as causing alterations in the actin cytoskeletal assembly, and inducing apoptosis and autophagic and necrotic cell death (6).

OCT is a rarely studied mouth rinse, which is known for its lower cytotoxicity than CHX (3). OCT is a cationic surfactant and bis-(dihydropyridinyl)-decane derivative used as a postoperative care agent for mucosal and cutaneous wounds. Schmidt et al. demonstrated that OCT had a lower cytotoxic activity on human fibroblasts and epithelial cells (3).

Although these two mouth rinses, $\mathrm{CHX}$ followed by OCT, are widely used in clinical practice, their cytotoxic effects could impair the early wound healing process. Some postoperative care agents enhance healing, especially in wound healing; HA induces beneficial early granulation tissue formation, inhibits destructive inflammatory reactions during the healing phase, and supports reepithelization and angiogenesis (7). HA is an anionic, non-sulfated glycosaminoglycan molecule and is the major carbohydrate component of the extracellular matrix of many biologic structures such as connective, epithelial, and neural tissues. HA is a multifunctional biologic structure. Its synthetic form has been used in many different medical fields, in ophthalmology for dry eyes and postoperative care, in dermatology as a dermal filler and for promoting wound healing, and in rheumatology for joint fluid replacement. In addition to these clinical uses, HA's synthetic form for topical oral use for enhancing postoperative wound healing has also been reported (7,8). Furthermore, Al- Bayaty et al. investigated HA's antimicrobial activity and concluded that $\mathrm{HA}$ was antimicrobial, but when compared with $\mathrm{CHX}$, its antimicrobial activity was very low (8).

Fibroblasts are crucial to the wound healing process. These cells are widely used in in vitro studies in order to examine cell behaviors during the wound healing process $(3,9)$. The purpose of this study was to investigate and compare the in vitro effects of $\mathrm{CHX}, \mathrm{OCT}$, and $\mathrm{HA}$ on human gingival fibroblasts' (HGFs) viability, apoptosis, proliferation, and migration in the early wound healing period using MTT assays, Annexin-V assays, and wound scratch assays.

\section{Materials and Methods}

\section{Human gingival fibroblast (HGF) culture}

HGFs were obtained from Erciyes University Betul-Ziya Eren Genome and Stem Cell Center (Kayseri, Turkey) and cultured in DMEM-Low Glucose (Biological Industries, Kibbutz Beit Haemek, Israel) supplemented with $10 \%$ fetal bovine serum (FBS), $100 \mathrm{IU} / \mathrm{mL}$ penicillin and streptomycin, and incubated at $37^{\circ} \mathrm{C}$ in a $5 \%$ humidified $\mathrm{CO} 2$ atmosphere. An ethical consideration was not required.
The samples of the study were divided into the four groups to compare effects of postoperative care agents. The groups were; chlorhexidine applied group (CHX), octenidine dihydrochloride applied (OCT) group, hyaluronic acid (HA) applied and nothing (contol group) were applied on human gingival fibroblasts' cell.

\section{Cell proliferation (MTT) assay}

MTT assays were performed to monitor cell proliferation and viability $(10,11)$. Cells were seeded at 5000 cells $/ \mathrm{cm}^{2}$ in $96-$ well plates in standard culture medium. The final concentration was $0.5 \mathrm{mg} / \mathrm{mL}$ MTT in standard culture medium after 24 h, $48 \mathrm{~h}$, and $72 \mathrm{~h}$ of culturing. Following $4 \mathrm{~h}$ of incubation, the MTT solution was removed and dimethyl sulfoxide was added to dissolve the formed formazan crystals. The culture dishes were agitated in a shaker for 10 minutes to ensure the dissolution of formazan crystals. Absorbance was measured at a wavelength of 560-750 nm using a Glomax Multi Detection System microplate reader (Promega, USA) (twelve replicates for each treatment).

\section{Annexin V and dead cell assay}

Apoptotic, live, and dead cells were detected using a fluorescein conjugated annexin V kit with a Muse EasyCyte flow cytometer following the manufacturer's instructions (Merck, Millipore, USA) (12). The average of the measurements from triplicate experiments was used in the calculation of the final data.

\section{Wound healing assay}

HGFs were grown to $95 \%$ confluence in 6 well-plates. A scratch wound was made by scratching the cells with a pipette tip (13). The cells were rinsed with $\mathrm{CHX}$ (Andorex ${ }^{\circledR}$, Pharmactive, Turkey), OCT (Octenidol ${ }^{\circledR}$, Schülke, Germany) and HA (Gencigel ${ }^{\circledR}$, Ricerfarma, Italy) solutions for 30 seconds. HGFs were incubated in standard culture medium at $37^{\circ} \mathrm{C}$ in a $5 \%$ humidified $\mathrm{CO} 2$ atmosphere. The wound area was photographed at the beginning, at $24 \mathrm{~h}$, and at $48 \mathrm{~h}$, and cell migration was assessed by measuring the gap size in at least

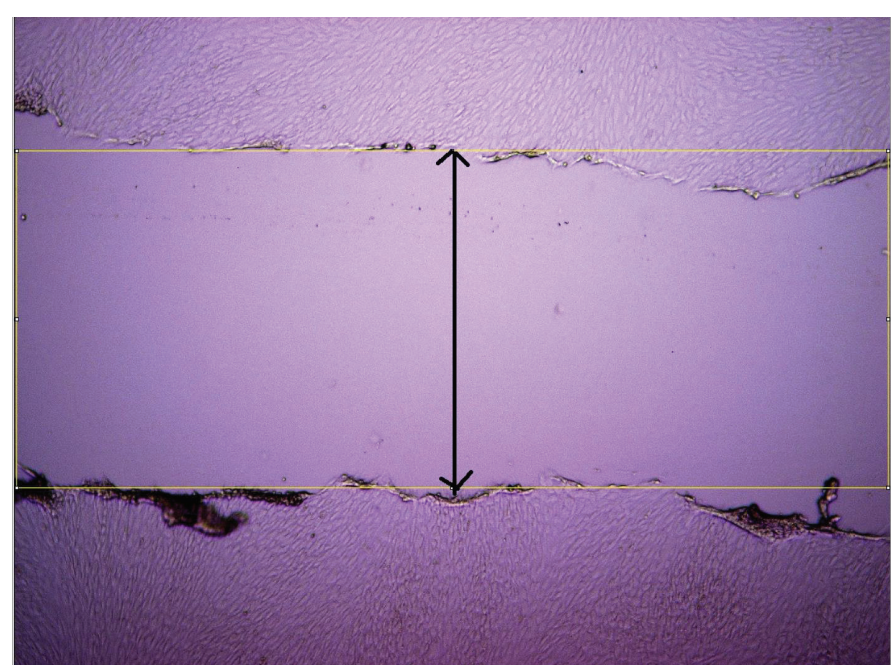

Figure 1. Calculating the width of the scratch wound by drawing and measuring vertical lines. 
10 fields using Image J (National Institute of Mental Health, Maryland, USA) (Figure 1). The average of the measurements from three experiments was used in the calculation of the final data. The migration rate is expressed as the percentage of scratch closure on an initial area basis, according to the following equation (At(Baseline) = scratch width at time 0 , and $A t=$ scratch width at $24 \mathrm{~h}$ and $48 \mathrm{~h}$ ) (14):

\section{Results}

\section{Cell proliferation}

Graphical data of cell proliferation are shown in Figure 2. Twenty-four, 48, and 72 hours after administration of the solutions, there were statistically significant differences in cell proliferation between the control group and experimental groups (Table 1). However, there were no differences between the mouth rinse groups for proliferation rates according to the MTT assay. The cell proliferation value of the control group was significantly higher than in the $\mathrm{CHX}$,

A

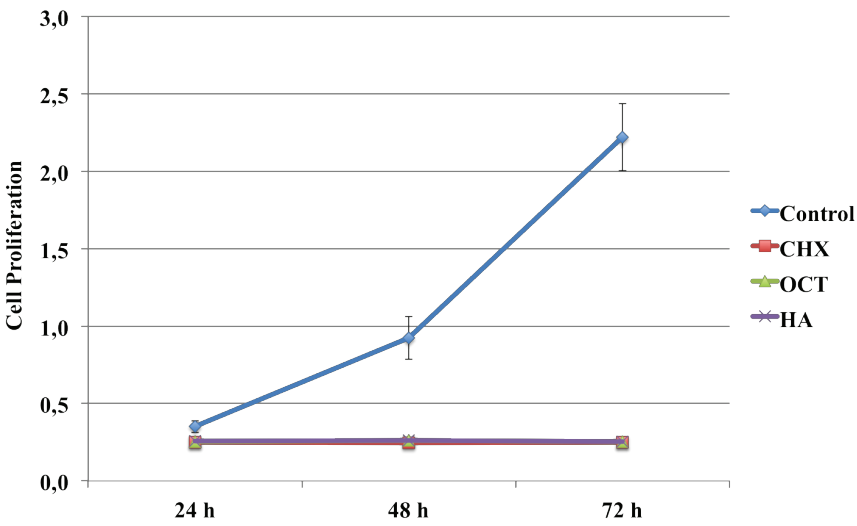

Figure 2. Time-dependent effects of $C H X, O C T$ and HA on HGFs' cell proliferation.
OCT, and HA groups $(p<0.001)$. There were no statistically significant differences in terms of cell proliferation between the $\mathrm{CHX}, \mathrm{OCT}$, and HA groups.

\section{Cell viability}

Graphical data of cell viability is presented in Figure 3. When both $\mathrm{CHX}$ and OCT solutions were applied, there were time-dependent statistically significant differences between the different times $(p=0.027)$ (Table 2). For both solutions, cell viability after $24 \mathrm{~h}$ was significantly higher than cell viability after $48 \mathrm{~h}$ and $72 \mathrm{~h}(\mathrm{p}=0.049)$. Cell viability in the CHX and OCT groups showed a decrease at $48 \mathrm{~h}$ and rose again after $72 \mathrm{~h}$. In both groups, there were statistically significant differences for cell viability after $48 \mathrm{~h}$ and $72 \mathrm{~h}(\mathrm{p}=0.049)$. For the control and HA groups, there were no time-dependent statistically significant differences $(p=0.148)$.

Twenty-four and 48 hours after administration of the solutions, there was a statistically significant difference in cell viability between the solutions $(p<0.05)$. There were no

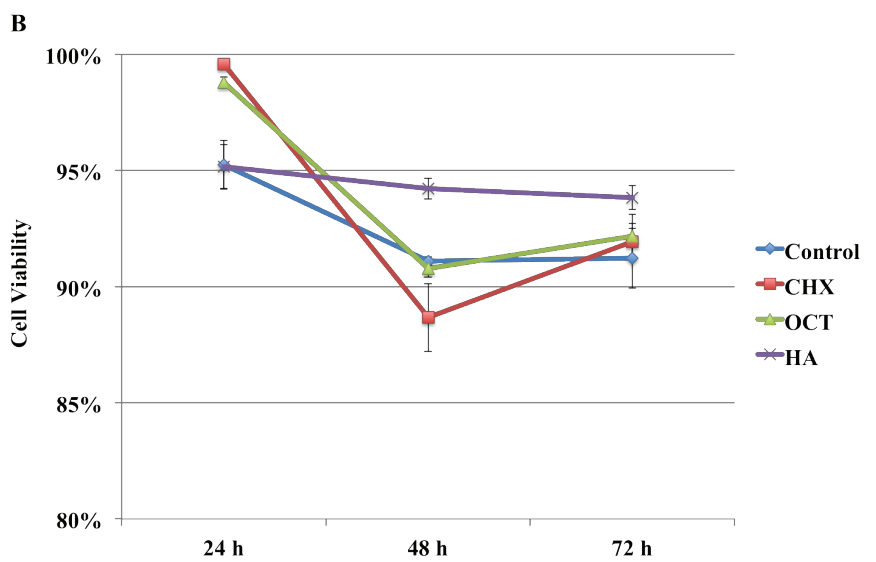

Figure 3. Time-dependent effects of CHX, OCT and HA on HGFs' Cell viability.

Table 1. Cell proliferation stratified by time periods (Post Hoc Tukey's test ${ }^{*} p<0.05$ ).

\begin{tabular}{lccc} 
MTT Assay & $\mathbf{2 4}$ hours \\
Mean \pm SD & 48 hours & Mean \pm SD & Mean $\pm S D$ \\
Control & $0.351 \pm 0.038$ & $0.9242 \pm 0.138$ & $2.2188 \pm 0.216$ \\
\hline CHX & $0.251 \pm 0.012$ & $0.2459 \pm 0.013$ & $0.2489 \pm 0.023$ \\
\hline OCT & $0.2515 \pm 0.016$ & $0.2627 \pm 0.018$ & $0.253 \pm 0.022$ \\
\hline HA & $0.2555 \pm 0.011$ & $0.26 \pm 0.014$ & $0.2539 \pm 0.023$ \\
\hline $\mathrm{P}$ & $0.002^{* *}$ & $0.008^{* *}$ & $<0.001^{* * *}$ \\
\hline
\end{tabular}

Table 2. Cell viability in different time periods.

\begin{tabular}{lcccc} 
Living HGFs (\%) & $\begin{array}{c}\mathbf{2 4} \text { hours } \\
\text { Mean } \pm \text { SD (median) }\end{array}$ & $\begin{array}{c}\mathbf{4 8} \text { hours } \\
\text { Mean } \pm \text { SD (median) }\end{array}$ & $\begin{array}{c}\mathbf{7 2} \text { hours } \\
\text { Mean } \pm \text { SD (median) }\end{array}$ & p \\
\hline Control & $95,25 \pm 1,05(95,35)$ & $91,10 \pm 0,18(91,05)$ & $91,23 \pm 1,29(91,45)$ & 0,061 \\
\hline CHX & $99,58 \pm 0,20(99,55)$ & $88,67 \pm 1,46(87,90)$ & $91,93 \pm 0,80(92,15)$ & $0,027^{*}$ \\
\hline OCT & $98,80 \pm 0,23(98,75)$ & $90,77 \pm 0,37(90,90)$ & $92,17 \pm 0,95(92,10)$ & $0,027^{*}$ \\
\hline HA & $95,17 \pm 0,94(94,95)$ & $94,22 \pm 0,45(94,15)$ & $93,83 \pm 0,51(93,70)$ & 0,148 \\
\hline P & $0,025^{*}$ & $0,022^{*}$ & 0,086 & \\
\hline
\end{tabular}


statistically significant differences in terms of cell viability between the $\mathrm{CHX}, \mathrm{OCT}, \mathrm{HA}$, and control groups after $72 \mathrm{~h}$.

\section{Total apoptotic cells}

Graphical data of total apoptotic cells are shown in Figure 4. When both $\mathrm{CHX}$ and OCT solutions were applied, there were time-dependent statistically significant differences between the different times for total apoptotic cell percentages $(p=0.027)$ (Table 3$)$. For both solutions, apoptotic cell percentages after $24 \mathrm{~h}$ were significantly lower than living cell percentages after $48 \mathrm{~h}$ and $72 \mathrm{~h}(\mathrm{p}=0.049)$. The apoptotic cell percentage in the CHX and OCT groups showed an increase at $48 \mathrm{~h}$ and declined again after $72 \mathrm{~h}$. In both groups, there were statistically significant differences for apoptotic cell percentages after $48 \mathrm{~h}$ and $72 \mathrm{~h}(\mathrm{p}=0.049)$. For the control and HA groups, there were no time-dependent statistically significant differences.

In the evaluation of the percentage of total apoptotic cells at $24 \mathrm{~h}, \mathrm{CHX}$ showed a statistically lower percentage than OCT $(p=0.049), H A(p=0.049)$, and the control group $(p=0.049)$. At

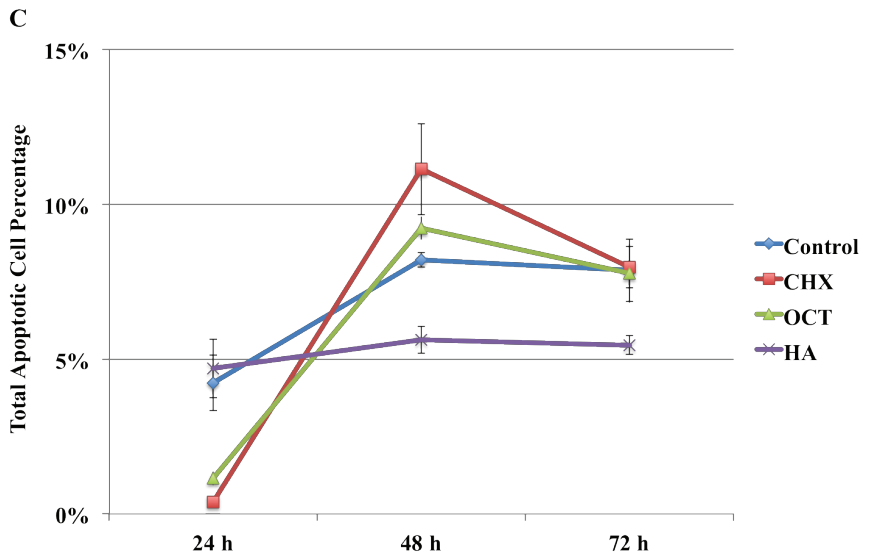

Figure 4. Time-dependent effects of CHX, OCT and HA on HGFs' total apoptotic cell percentage.
$48 \mathrm{~h}, \mathrm{HA}$ showed a statistically lower percentage of apoptotic cells than the $\mathrm{CHX}(p=0.049)$ and control groups $(p=0.049)$. CHX and OCT may prevent early apoptosis at $24 \mathrm{~h}$; however, there were no statistically significant differences between the solutions at $72 \mathrm{~h}$.

\section{Gap closure rate}

Graphical data of gap closure rates are given in Figure 5. CHX, OCT, and HA solutions had an inhibitory effect on HGF migration according to the wound healing assay. 24 and 48 hours after administration of the solutions, there was a statistically significant difference between the control group and the test groups $(p<0.001)$ (Table 4). OCT showed a statistically worse effect on HGF migration than $\mathrm{CHX}(\mathrm{p}=0.01)$ and $\mathrm{HA}(\mathrm{p}=0.01)$ at $24 \mathrm{~h} . \mathrm{CHX}$ and HA maintained the ability of HGF migration better than OCT at $48 \mathrm{~h}(\mathrm{p}=0.01, \mathrm{p}<0.001$, respectively). $\mathrm{CHX}$ and $\mathrm{HA}$ had a similar effect according to the wound healing assay. Inhibition of cell migration was observed in the $\mathrm{CHX}, \mathrm{OCT}$, and $\mathrm{HA}$ groups in the scratch gap tests (Figure 6).

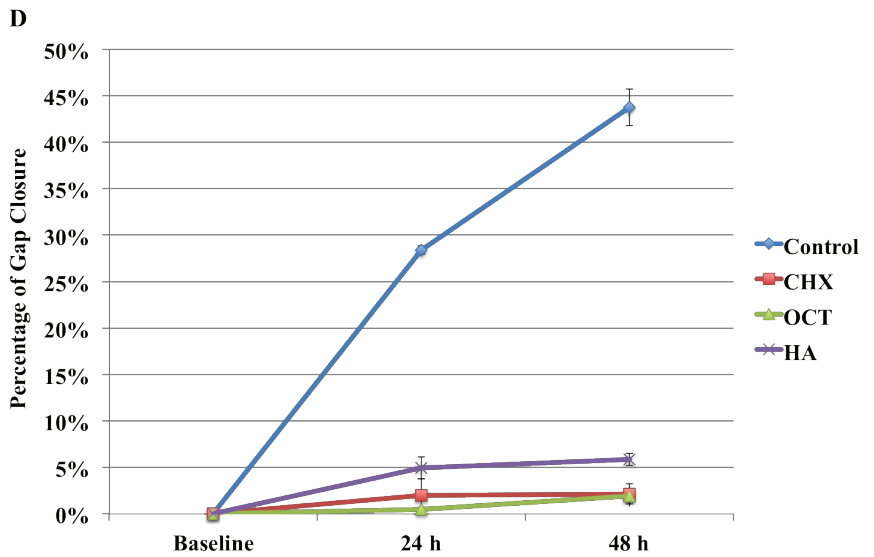

Figure 5. Time-dependent effects of CHX, OCT and HA on Gap Closure Rate in the wound scratch assay.

Table 3. Total apoptotic cell percentage for different time periods.

\begin{tabular}{lcccc} 
Total apoptotic HGFs (\%) & $\begin{array}{c}\mathbf{2 4} \text { hours } \\
\text { Mean } \pm \text { SD (Median) }\end{array}$ & $\begin{array}{c}\mathbf{4 8} \text { hours } \\
\text { Mean } \pm \text { SD (Median) }\end{array}$ & $\begin{array}{c}\mathbf{7 2} \text { hours } \\
\text { Mean } \pm \text { SD (Median) }\end{array}$ & \\
\hline Control & $4.23 \pm 0.90(4.30)$ & $8.20 \pm 0.23(8.25)$ & $7.87 \pm 1.01(7.70)$ & 0.061 \\
\hline CHX & $0.38 \pm 0.16(0.45)$ & $11.13 \pm 1.47(11.8)$ & $7.97 \pm 0.67(7.80)$ & $0.027^{*}$ \\
\hline OCT & $1.15 \pm 0.22(1.25)$ & $9.23 \pm 0.37(9.10)$ & $7.77 \pm 0.95(7.80)$ & $0.027^{*}$ \\
\hline
\end{tabular}

Table 4. Gap closure rate (*statistically significant).

\begin{tabular}{lcc}
$\begin{array}{l}\text { Wound scracth assay gap } \\
\text { closure rate (\%) }\end{array}$ & $\begin{array}{c}\mathbf{2 4} \text { hours } \\
\text { Mean } \pm \text { SD }\end{array}$ & $\begin{array}{c}\mathbf{4 8} \text { hours } \\
\text { Mean } \pm \text { SD }\end{array}$ \\
\hline Control & $28.42 \pm 0.81$ & $43.74 \pm 3.44$ \\
\hline CHX & $1.99 \pm 3.11$ & $2.15 \pm 1.90$ \\
\hline OCT & $0.50 \pm 0.72$ & $1.91 \pm 1.91$ \\
\hline HA & $4.94 \pm 2.01$ & $5.87 \pm 1.16$ \\
\hline$p$ & $<0.001^{*}$ & $<0.001^{*}$ \\
\hline
\end{tabular}

\section{Discussion}

In this study, HGFs were chosen to analyze the cytotoxic effects of $\mathrm{CHX}, \mathrm{OCT}$, and $\mathrm{HA}$, because fibroblasts are essential to the wound healing process. After homeostasis and clot formation, wounds enter the proliferative step. Fibroblasts are one of the primary cell types that expand during this phase, driven by a burst of growth hormones supplied by the inflammatory response (15). The proliferative potential of 


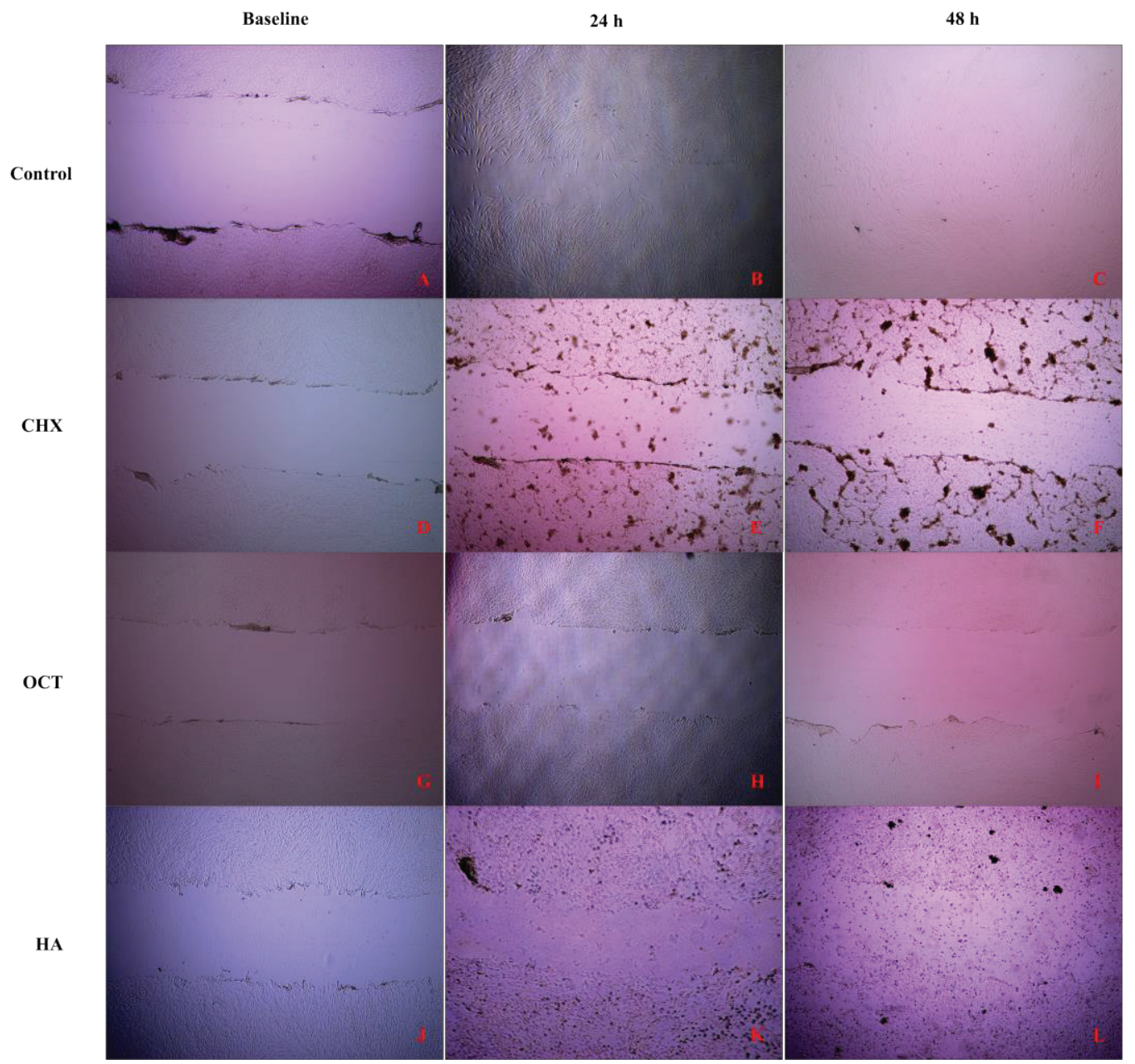

Figure 6. Gap closure views of control, CHX, OCT and HA groups at baseline, $24 \mathrm{~h}$ and $48 \mathrm{~h}$.

fibroblasts in the wound bed appears to drive the course of the healing process (16).

$\mathrm{CHX}$ is the most widely used and verified agent, having a broad activity spectrum against oral pathogens with good tolerability (17). Löe and Schiott defined CHX as the gold standard of mouth rinses in 1970 (4). The most important advantage of $\mathrm{CHX}$ is the very high level of substantivity, which leads to prolonged adherence of the antiseptic on hard and soft oral tissue. Therefore, the antiseptic is gradually released at an effective dose, which assures the persistence of its antimicrobial effect (18).

However, negative effects of $\mathrm{CHX}$ on human alveolar bone cells, stem cells from buccal fat pads, and HGFs were observed in many studies $(1,9,18)$. Cabral and Fernandes analyzed osteoblastic cells in vitro using MTT assays and suggested that $\mathrm{CHX}$ had a negative effect on cell growth of osteoblastic cells (1). Furthermore, Eick et al. demonstrated that commercially available $\mathrm{CHX}$ had a very strong cytotoxic effect on HGFs in MTT assays at different concentrations (9). Park et al. analyzed cell viability of stem cells derived from buccal fat pads using cell counting kit-8 (CCK-8) assays and found that both $\mathrm{CHX}$ and Listerine had negative effects on cell viability and relative viability (19). Schmidt et al. compared the cytotoxic effects of CHX and OCT using MTT assays and found that OCT had a lower cytotoxic potential on HGFs and human nasal epithelial cells in the applied concentration compared with $\mathrm{CHX}$ (3). An in vitro study on $L 929$ cells (ATCC CCL 1) derived from an immortalized mouse fibroblast cell line, which is routinely used in in vitro cytotoxicity assessments, by Müller and Kramer reported that OCT was less cytotoxic than several antiseptic solutions including $\mathrm{CHX}$, benzalkonium chloride, cetylpyridinium chloride, mild silver protein, polyhexamethylene biguanide, povidone iodine in solution, povidone iodine in ointment, silver (I) sulfadiazine, and triclosan (20). In the present study, all of the studied postoperative care agents showed a statistically significant negative effect on cell viability compared with the control group in the MTT assays. A comparison of the experimental groups showed no statistically significant differences between them.

In the literature, it was suggested that exogenous HA application could decrease the inflammatory response and prevent oxygen free-radical damage after tooth extraction $(21,22)$. HA has a moderating effect by erasing free radicals (23). Mendoza et al. reviewed all available data on the features and clinical profile of $\mathrm{HA}$ and they claimed that HA could erase free radicals (24). In a study conducted by Ye et al., it was suggested that high-molecular- weight HA could be an effective protective agent that had antioxidant properties (25). Gocmen et al. investigated the antioxidant and antiinflammatory effect of HA and reported that it had an antiinflammatory effect following wisdom tooth extraction. However, the oxidative stress levels and clinical outcomes were similar after one week. The authors suggested that according to their histologic data, HA application showed a lower inflammatory response. However, the clinical outcomes after one week showed no significant differences between the 
groups. The authors claimed that the reason for this difference was that postoperative sequelae generally resolve within one week (2). The better cell viability and apoptosis findings of the HA group in this study compared with other groups might be related to this anti-inflammatory characteristic.

In this present study, on comparing cell viability and apoptosis, the findings showed concordance with each other. At $24 \mathrm{~h}, \mathrm{CHX}$ showed better results compared with OCT and $\mathrm{HA}$, but at $48 \mathrm{~h}, \mathrm{HA}$ showed better results than all groups including the control group. These data suggest that HA might have a positive effect on cell viability and apoptosis at $48 \mathrm{~h}$.

\section{Conclusion}

All the mouth rinses had similar effects on cell behavior such as viability, apoptosis, and cell proliferation. Although the results of the present study support the hypothesis that $\mathrm{CHX}, \mathrm{OCT}$, and HA prevent cell migration and maintain HGF viability, OCT showed a greater statistically negative effect for HGF migration ability than $\mathrm{CHX}$ and $\mathrm{HA}$. The reason of the negative effect of $\mathrm{HA}$ on cell migration and viability could be the concentration used in this experiment. Different concentrations at different times for these agents should be further studied. Additional experiments that investigate other parameters such as cell differentiation, collagen synthesis and breakdown, inflammatory response, and growth factor release should be conducted in order to understand the effects of these agents at a molecular level. Additionally, in this experiment, the antimicrobial effects of these agents were not evaluated. Finding the balance between bactericidal effects without cellular toxicity is important for long-term postoperative treatment. Further experimental and clinical studies are needed to evaluate the antimicrobial effects of $\mathrm{CHX}, \mathrm{OCT}$, and $\mathrm{HA}$; therefore, it would be more suitable to combine these findings with the cellular effects of these agents in order to understand their clinical effects.

Türkçe Öz: Ameliyat sonrası kullanılan bakım ürünlerinin insan diş eti fibroblastlarına etkilerinin karşılaştırılmasi: ön çalışma. Amaç: Bu çalısmanın amacı postoperatif bakım ajanları olan; klorheksidin, oktenidin dihidroklorür ve hiyalüronik asitin insan gingival fibroblastlarının canlılığı, proliferasyonu, apoptozisi ve migrasyonu üzerine etkilerini karşılaştırmaktır. Gereç ve Yöntem: Hücre kültüründen sonra; klorheksidin, oktenidin dihidroklorür, hiyalüronik asit çözeltileri hücrelere uygulandı ve kontrol grubu için hücrelere hiçbir şey uygulanmadı. Hücrelerin apoptotik, canlı ve ölü hücre yüzdeleri sitotoksisiteyi araştırmak amacıyla 24, 48 ve 72 saat izlendi. Hücre migrasyonunu saptamak için yara tahmini testi yapıldı ve hücrelerin başlangıç, 24. saat ve 48 . saat takipleri yapıldı. Bulgular: 24 saat sonra, klorheksidin; oktenidin dihidroklorür $(p=0.049)$, hiyalüronik asit $(p=0.049)$ ve kontrol $(p=0.049)$ 'dan istatistiksel olarak daha düşük toplam apoptotik hücre yüzdesi gösterdi. 48. saatte, hyalüronik asit; klorheksidin $(p=0.049)$ ve kontrol $(p=0.049)^{\prime}$ 'dan istatistiksel olarak daha düşük apoptotik hücre yüzdesi gösterdi. Tüm ajanlar kontrol grubuna göre istatistiksel olarak daha fazla sitotoksik bulundu. Bununla birlikte, çoğalma oranı açısından deney grupları arasında fark yoktu. Oktenidin dihidroklorür, hücre göçünde 24. saatte klorheksidin ve hiyalüronik asitten istatistiksel olarak daha negatif etki gösterdi. 48. saatte klorheksidin ve hiyalüronik asitoktenidin hücre migrasyon kapasitesi octenidin dihidrokloritten daha fazla bulundu. Sonuç: Tüm ajanlar canlılı, apoptoz ve hücre proliferasyonu gibi hücre davranışları üzerinde benzer etkilere sahiptir. Bununla birlikte, oktenidin dihidroklorür; klorheksidin ve hiyalüronik aside göre, hücre göç etme kapasitesi üzerinde istatistiksel olarak daha olumsuz bir etki gösterdi. Anahtar Kelimeler: Klorheksidin; hiyalüronik asit; oktenidin dihidroklorit; hücre canlılığı; hücre göçü

\section{Ethics Committee Approval: Not required.}

Informed Consent: Not required.

Peer-review: Externally peer-reviewed.

Author contributions: UM, ZBG and HS participated in designing the study. UM and ZBG participated in generating the data for the study. ZBG, GMYU and DGM participated in gathering the data for the study. UM participated in the analysis of the data. UM, ZBG, GMYU and DGM wrote the majority of the original draft of the paper. UM, ZBG, HS and GMYU participated in writing the paper. All authors approved the final version of this paper.

Conflict of Interest: The authors have no conflicts of interest to declare.

Financial Disclosure: The authors declared that this study has received no financial support.

\section{References}

1. Cabral CT, Fernandes MH. In vitro comparison of chlorhexidine and povidone-iodine on the long- term proliferation and functional activity of human alveolar bone cells. Clin Oral Investig 2007;11(2):155-64. [CrossRef]

2. Gocmen G, Gonul O, Oktay NS, Yarat A, Goker K. The antioxidant and anti-inflammatory efficiency of hyaluronic acid after third molar extraction. J Craniomaxillofac Surg 2015;43(7):1033-7. [CrossRef]

3. Schmidt J, Zyba V, Jung K, Rinke S, Haak R, Mausberg RF, Ziebolz D. Cytotoxic effects of octenidine mouth rinse on human fibroblasts and epithelial cells - an in vitro study. Drug Chem Toxicol 2016;39(3):322-30. [CrossRef]

4. Löe H, Schiott CR. The effect of mouthrinses and topical application of chlorhexidine on the development of dental plaque and gingivitis in man. J Periodontal Res 1970;5(2):79-83. [CrossRef]

5. Li YC, Kuan YH, Lee SS, Huang FM, Chang YC. Cytotoxicity and genotoxicity of chlorhexidine on macrophages in vitro. Environ Toxicol 2014;29(4):452-8. [CrossRef]

6. Hidalgo E, Dominguez C. Mechanisms underlying chlorhexidineinduced cytotoxicity. Toxicol In Vitro 2001;15(4-5):271-6. [CrossRef]

7. Koray $M$, Ofluoglu $D$, Onal Ea, Ozgul $M$, Ersev $H$, Yaltirik $M$, Tanyeri H. Efficacy of hyaluronic acid spray on swelling, pain, and trismus after surgical extraction of impacted mandibular third molars. Int J Oral Maxillofac Surg 2014;43(11):1399-403. [CrossRef]

8. Al-Bayaty1 FH, Taıyeb-Ali TB, Abdulla MA, Mahmud ZB. Antibacterial effects of Oradex, Gengigel and Salviathymol-n mouthwash on dental biofilm bacteria. Afr J Microbiol Res 2011;5(6): 636-642.

9. Eick S, Goltz S, Nietzsche S, Jentsch H, Pfister W. Efficacy of chlorhexidine digluconate- containing formulations and other mouthrinses against periodontopathogenic microorganisms. Quintessence Int 2011;42(8):687-700.

10. Van Meerloo J, Kaspers GJ, Cloos J. Cell sensitivity assays: the MTT assay. Methods Mol Biol 2011;731:237-45. [CrossRef]

11. Stockert Jc, Blázquez-Castro A, Ca-ete M, Horobin Rw, Villanueva A. MTT assay for cell viability: Intracellular localization of the formazan product is in lipid droplets. Acta Histochem 2012;114(8):785-96. [CrossRef]

12. Pietkiewicz S, Schmidt JH, Lavrik IN. Quantification of apoptosis and necroptosis at the single cell level by a combination of Imaging Flow Cytometry with classical Annexin V/propidium iodide staining. J Immunol Methods 2015;423:99-103. [CrossRef] 
13. Liang CC, Park AY, Guan JL. In vitro scratch assay: a convenient and inexpensive method for analysis of cell migration in vitro. Nat Protoc 2007;2(2):329-33. [CrossRef]

14. Felice F, Zambito Y, Belardinelli E, Fabiano A, Santoni T, Di Stefano R. Effect of different chitosan derivatives on in vitro scratch wound assay: a comparative study. Int J Biol Macromol 2015;76:236-41. [CrossRef]

15. Bucalo B, Eaglstein WH, Falanga V. Inhibition of cell proliferation by chronic wound fluid. Wound Repair Regen 1993;1(3):181-6. [CrossRef]

16. Thomas GW, Rael LT, Bar-Or R, Shimonkevitz R, Mains CW, Slone DS, Craun ML, Bar-Or D. Mechanisms of delayed wound healing by commonly used antiseptics. J Trauma 2009;66(1):82-90; discussion 90-1. [CrossRef]

17. Seymour RA, Heasman PA, Macgregor IDM Anti-plaque and anti-calculus agents. In: Seymour RA, Heasman PA (eds) Drugs, diseases and the periodontium. Oxford Medical Publications, Hong Kong, 1992, pp 153-179.

18. Cousido MC, Tomás Carmona I, García-Caballero L, Limeres J, Alvarez M, Diz P. In vivo substantivity of $0.12 \%$ and $0.2 \%$ chlorhexidine mouthrinses on salivary bacteria. Clin Oral Investig 2010;14(4):397-402. [CrossRef]

19. Park JB, Lee G, Yun BG, Kim CH, Ko Y. Comparative effects of chlorhexidine and essential oils containing mouth rinse on stem cells cultured on a titanium surface. Mol Med Rep 2014;9(4):1249-53. [CrossRef]
20. Müller G, Kramer A. Biocompatibility index of antiseptic agents by parallel assessment of antimicrobial activity and cellular cytotoxicity. J Antimicrob Chemother 2008;61(6):1281-7. [CrossRef]

21. Foschi D, Castoldi L, Radaelli E, Abelli P, Calderini G, Rastrelli A, Mariscotti C, Marazzi M, Trabucchi E. Hyaluronic acid prevents oxygen free-radical damage to granulation tissue: a study in rats. Int J Tissue React 1990;12(6):333-9.

22. Brown JA. The role of hyaluronic acid in wound healing's proliferative phase. J Wound Care 2004;13(2):48-51. [CrossRef]

23. Presti $D$, Scott JE. Hyaluronan-mediated protective effect against cell damage caused by enzymatically produced hydroxyl $(\mathrm{OH}$.) radicals is dependent on hyaluronan molecular mass. Cell Biochem Funct 1994;12(4):281-8. [CrossRef]

24. Mendoza G, Prieto JG, Real R, Pérez M, Merino G, Alvarez Al. Antioxidant profile of hyaluronan: physico-chemical features and its role in pathologies. Mini Rev Med Chem. 2009;9(13):147988. [CrossRef]

25. Ye J, Wu H, Wu Y, Wang C, Zhang H, Shi X, Yang J. High molecular weight hyaluronan decreases oxidative DNA damage induced by EDTA in human corneal epithelial cells. Eye (Lond) 2012;26(7):1012-20. [CrossRef] 